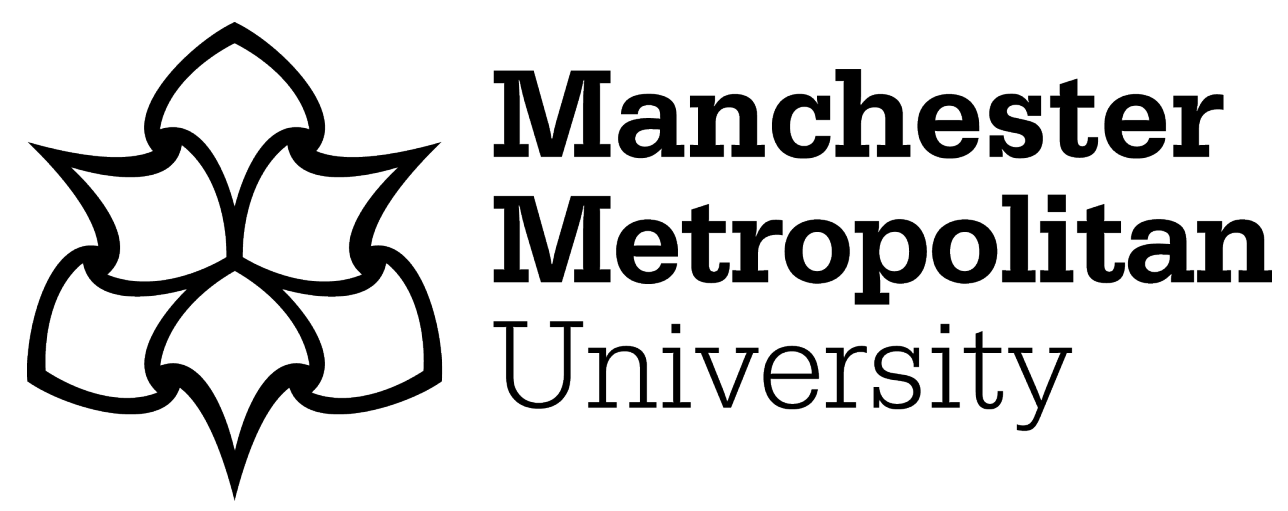

Stockmann, Daniela, Garten, Felix and Luo, Ting (2020) Who is a PRC user? Comparing Chinese social media user agreements. First Monday, 25 (8).

Downloaded from: https://e-space.mmu.ac.uk/626282/

Version: Published Version

Publisher: University of Illinois Libraries

DOI: https://doi.org/10.5210/fm.v25i8.10319

Please cite the published version 


\section{Who is a PRC User? Comparing Chinese Social Media User Agreements}

Daniela Stockmann, PhD, Hertie School, stockmann@hertie-school.org

Felix Garten, Hertie School, garten@hertie-school.org

Ting Luo, PhD, Manchester Metropolitan University, tingltlse@gmail.com

\section{Funding statement}

The research leading to these results has received funding from the European Research Council under the European Union's Seventh Framework Programme (FP/2007-2013) / ERC Grant Agreement n. [338478]. The Hertie School of Governance and Leiden University are both beneficiaries of the grant.

\section{Abstract:}

Social media companies rely on user agreements as one means to manage content produced by users. While much has been written on user agreements and community standards of USbased social media, surprisingly little is known about Chinese user agreements and their implications. We compare terms of services as well as privacy policies of WeChat and Weibo between 2014 and 2019 using their US-counterparts WhatsApp and Twitter as a benchmark. We find that Chinese user agreements reveal a territorial-based understanding of content management differentiating between PRC and Non-PRC users based on language, IP address and country of citizenship. Second, Chinese social media companies are surprisingly transparent about what content can be published, which has implications for self-censorship among users. Third, changes in PRC User agreements reflect Xi Jinping's tightening control of 
the Internet. Finally, US-based platforms have moved towards content management that differs by region, thus becoming more similar to the Chinese approach over time.

Keywords: Social media, content management, censorship, user agreements, privacy, China, Twitter, WhatsApp, WeChat, Weibo. 


\section{Introduction}

Social media companies across the world are taking on an important role in managing and controlling Internet content. They are using a variety of means to do so, such as automatic upload filtering, user reporting, and user agreements. Social media platforms have become "proxy censors" regulating content with regards to government and own commercial interests (Hintz, 2016, p. 340).

While a large literature exists on terms of use, community standards, privacy policies, and information regarding data processing of US-based companies (Celeste, 2019; Hintz and Milan, 2011; Leistert, 2015; Lovink, 2013; Silverman, 2015; Youmans and York, 2012), little is known about Chinese user agreements aimed at regulating and managing content. This is surprising given China's 772 million Internet users, making up the largest group of Internet users in the world (China Internet Network Information Center, 2018). In addition, Chinese companies have started to serve as examples for important companies outside of China. For example, Facebook has been observing WeChat's integration into Tencent's e-finance system very closely (Jacobs, 2019).

Chinese social media companies operate in a drastically different environment than USbased companies. Social media platforms are first defined as media in China and only second as products of private companies. As a result, they are integrated into China's political structure whereby companies are subject to an elaborate state administrative structure led by the 
Cyberspace Administration of China in charge of regulating online content [1]. Within this institutional infrastructure the implementation of content management is outsourced to private companies, whereby Chinese companies rely on similar mechanisms as their counterparts outside of China to manage content (see, for example, Cairns, 2016). Here, we focus on user agreements as one such important mechanism: How do Chinese social media companies communicate restrictions to users? What do Chinese user agreements have in common and how does this approach differ from their US counterparts?

We compare Weibo and WeChat user agreements composed of terms of services and privacy policies between 2014 and 2019. Due to similarities of the platforms user agreements of Twitter and WhatsApp are used as a benchmark for reference. We are not systematically comparing Chinese and U.S.-based user agreements in order to draw conclusions about differences between these two countries. We highlight four key findings: First, Chinese user agreements reveal a territorial-based understanding of content management. Social media companies differentiate between users based on their language, IP address and country of citizenship. So-called PRC Users, defined as people holding a Chinese passport, people entering the territory of the PRC, or Chinese-incorporated companies, have to abide by PRC-specific user agreements, whereas Non-PRC Users have very similar rights to users from US-based companies. Second, Chinese social media companies are surprisingly transparent regarding censorship, personal information and data processing to enforce self-censorship among its netizens. Third, 
changes in PRC User agreements reflect Xi Jinping's tightening control of the Internet. During the first five years of his rule the Chinese Communist Party (CCP) has centralized China's state administrative bodies in charge of regulating online content (Cairns, 2016; Creemers, 2017). Changes in user agreements reflect this broader trend. Finally, while we do not find evidence for a territorial-based approach among US-based companies in 2014, Twitter and Facebook have moved towards content management that differs by region in 2019 , thus becoming more similar to the Chinese approach over time.

To provide background we start laying out China's approach towards legal reform and content management of social media companies, followed by an explanation of the above main findings. We conclude with a discussion, placing findings from China within broader trends in content management.

\section{China's Legal System and the Approach Towards Content Management}

In contrast to liberal democracies characterized by 'rule of law', the Chinese state operates within 'rule by law', whereby the Chinese Communist Party assumes a privileged position above the law and the government (Wang and Liu, 2019). For example, during the recent anti-corruption campaign President Xi Jinping ordered corruption investigations against party members sidelining the general bureaucratic body (Heilmann, 2016; Visualizing China's Anti-Corruption Campaign, 
2018). This explains the top-down nature of the party giving directives to the Chinese judicial system and the government.

However, China has also undergone legal reform which weakens the top-down nature of rule by law. As part of legal reform the government directs decision-making by mostly local officials to courts, not allowing party officials to intervene in judicial processes (Liebman, 2017). Wang and Liang (2019) demonstrate that government officials also empower courts to effectively respond to environmental protection in Guiyang. The Chinese political system is therefore not characterized by a fully centralized hierarchical structure; instead, China experts have long emphasized the fragmented nature of the Chinese authoritarian state promoting legal reforms for more effective governance (see, for example, Lieberthal and Lampton, 1992). In the words of Cheesman (2014, p. 113): the Chinese ruling elites are not on the "low rungs on a ladder to the rule of law; they are climbing a different ladder altogether."

More specifically regarding content management, China has built an extensive infrastructure for media governance within which social media companies are integrated. Chinese media remain embedded into a sophisticated institutional framework that monitors media content and gives directives to media when content is undermining official policies and goals of the government. Yet along with the introduction of market forces in media and the development of new communication technologies, such as the Internet and cell phones, the CCP has moved 
away from using overt techniques of giving directives to media professionals to increasingly relying on softer and more subtle techniques (Stockmann, 2013).

In terms of media governance the state has been strengthening the legal system and has been fostering self-regulation among journalists. Chinese media are often solving disputes with officials in the courtroom where they lose most defamation cases brought against them (Liebman, 2011). The Chinese state has also promoted training and education of journalists in exercising “societal responsibility" (社会责任) (Dombernowsky, 2016, p. 184) - a synonym for behaving in line with the goals and policies of the CCP, which is part of the ethical code. At the same time, critical investigative journalism has faced challenges, even more after Xi Jinping came into office (Tong, 2019).

On social media, paid bloggers known as "50-cent party members" in combination with subtle technology, such as technical error messages that are displayed when information is deleted or blocked, create difficulties to detect censorship in the eyes of users (Bandurski, 2008; Boas, 2006; Brady, 2008; Chase et al., 2002; MacKinnon, 2009; Qiu, 2000) [2]. To incentivize Internet companies to conform to censorship policies, companies have been awarded selfdiscipline awards for displaying social responsibility [3]. At the same time, legal regulations passed towards the end of Hu Jintao's and beginning of Xi Jinping's rule form the basis to punish individual users for messages that go viral and potentially challenge social stability and deter users 
from publishing and spreading such messages. Anyone deliberately posting lies may face up to three years in prison, if their posts are shared more than 500 times or viewed by more than 5,000 people [4]. After years of resistance among Chinese netizens, real name registration, under which every user is required to register with the real name for the general use of Internet services, was implemented in 2015 (Li, 2015) [5]. User agreements are part of this effort to become more transparent about rules for deletion and blocking of content; by speaking directly to users they aim to educate users about rules for self-censorship associated with socially responsible behavior. In China transparency is used to improve implementation of policies with the broader goal of supporting the survival of the party (Stromseth et al, 2017). With greater openness of information regarding what is socially desirable, the central government tries to encourage citizens and media to monitor the Internet for misconduct, while at the same time strengthening the position of the CCP (Stromseth et al, 2017).

Overall Xi's administration has tightened the control over the Internet by introducing a complementary system of legal and regulatory measures that influence behavior among Internet users directly as opposed to working solely via Internet companies (Creemers, 2017). It is important to keep this context in mind when interpreting content of Chinese user agreements over time and in relation to their US-counterparts. 


\section{Research Methods}

We collected user agreements composed of terms of service and privacy policies from the official website of Weibo owned by Sina and WeChat owned by Tencent. As a baseline for comparison we also collected those by their respective US counterparts Twitter and WhatsApp. We also checked which user agreement was available to users depending on whether the App was used in English or Chinese (simplified and traditional). As shown in Table 1, Chinese user agreements divide into Non-PRC User and PRC User versions.

[Please insert Table 1 about here]

We compared these user agreements in terms of structure, regulations on user-uploaded contents, and differentiation of PRC Users and Non-PRC Users in 2014 and 2019. We proceeded in three steps: first, we compared the Chinese versions to the English version from the same company to see how WeChat and Weibo treat PRC and Non-PRC Users; second, we used user agreements of U.S.-based platforms as a benchmark, to highlight the specific characteristics of Chinese user agreements. Third, we compared 2014 and 2019 versions of Weibo and WeChat to identify changes over time. 


\section{Toward a Territorial-based Approach of Content Management}

The two Chinese companies, Sina and Tencent, distinguish between PRC and Non-PRC Users in their user agreements, whereby users receive different versions depending on their language preferences. For example, WeChat defined PRC Users in the following way:

"These Terms apply to you if you are a user of our services anywhere in the world other than the People's Republic of China (and you are not a citizen of the People's Republic of China). If you are: (i) a user of our services in the People's Republic of China; (ii) a citizen of the People's Republic of China using our services anywhere in the world; or (iii) a Chinese-incorporated company using our services anywhere in the world, please refer to the Terms of Service (PRC Users) for the terms that apply to you in your use of our services."

When selecting simplified Chinese (简体中文) on the international homepage, users will be redirected to the PRC homepage of WeChat. This website only provides the PRC version (English and Chinese) of the user agreement. The version for Non-PRC Users is not mentioned. Hence, language defines a digital boundary between the PRC and the international versions of user agreements. As mentioned above, another filter is the IP address. If users have an IP address from China, they will be automatically directed to the PRC version without having an option to choose the international version in the first place. Weibo uses the same mechanisms - language 
preferences and IP address - to differentiate PRC and Non-PRC Users, but it does not provide a definition of PRC Users.

While the 2014 Non-PRC version of WeChat applies additional laws to users from the US and Australia, the 2019 Non-PRC version also includes the EU. Interestingly, Weibo does not make this differentiation at all. All user agreements of Weibo in 2014 and 2019 are based on the law of the PRC.

In comparison, the two US-based social media companies do not treat users differently depending on location, language, or IP address; one version is available in English for all users (see Table 1). Nevertheless, US-based social media differentiate between users according to regions they are based in. WhatsApp refers to different headquarters being responsible for European and non-European users in 2019. This regional separation does not appear in 2014. Twitter also differentiates between users in 2019. They provide one version of terms of service that only applies to US-American netizens and one for all international users. This points towards greater territorial-based approach towards content management over time, even among US-based companies. Different to the Chinese social media user agreements, US based social media does not define digital boundaries between its users. All users can access the different versions of the user agreements. 


\section{Toward Greater Transparency}

China's division into PRC and Non-PRC user agreements is significant, because the PRC version aims to make content management transparent to users. The PRC user agreements of Weibo and WeChat contain a section on user behavior and conditions for using the applications. WeChat explicitly states that users have to take responsibility for all actions on their accounts, whereas Weibo makes users responsible for content they post. Twitter and WhatsApp also mention that users are responsible for posted content, but provide less restrictions for political content.

Before we engage with rules for content management we first take a closer look at how social responsibility is defined as this concept lays out expectations for acceptable user behavior. Weibo and WeChat provide descriptions of their general expectation of user behavior. Weibo is explicit about what the social responsibility of a user should entail:

"Users should be civilized, respect personal rights and privacy of other users and they should build together a harmonious, civilized and polite social network environment."

WeChat, however, provides a vague description, appealing to contributing to an overall respectful environment. Although this general description leaves room for interpretation, these rules are meant to educate users about which content can be published based on appeals towards healthy and civil discourse. 
Similar to US-based user agreements, Chinese terms of services are embedded into a legal framework, but in this case the laws and regulations of the PRC. According to terms of services users are not allowed to cover content [8]:

(1) against the basic principles of the constitution;

(2) endangering state security, disclosing state secrets to subvert state power or disrupt national unity;

(3) damaging national reputation and interest;

(4) stirring up ethnic hatred, ethnic discrimination and undermining national unity;

(5) undermining the country's religious policies to promote cults and feudal superstitious;

(6) spreading rumors, disturbing social order, undermining social stability;

(7) spreading obscenity, pornography, gambling, violence, murder, terror or instigation crime;

(8) insulting or slandering others, infringing upon the lawful rights and interests of others;

(9) infringing on intellectual property rights of any third party, copyright, reputation and trade secrets

(10) violating human morality, customs and habits. 
(11) any form of advertising without permission from the Internet platform provider is not allowed.

These rules are not contained in Non-PRC User versions. Rules 1-6 in particular specify the correct political usage of the social media platform. By making clear that social media should not be used to undermine the constitution, state security, national reputation or national unity, IT companies remind users that social media, just like traditional media, should only be used in ways that uphold the CCP's leadership and the party's organizational principles and policies [9]. All changes to the constitution made under Xi Jinping's rule in 2018 also apply to user agreements [10]. Similarly, users should not undermine China's unity, making an implicit reference to ethnic conflict and segregation movements in Xinjiang and Tibet as well as religious movements, such as Falun Gong, that could potentially threaten CCP rule and national unity [11]. Overall, users have to follow the official line that demands support of unity and leadership under the rule of the CCP led by Xi Jinping.

False information has been an important aspect of content management in China since the introduction of advertising as an alternative funding of media outlets (Stockmann, 2013). Under Xi Jinping new legal regulations were passed that shed light on the definition of false information and rumors [12]. In line with these legal regulations, references to rumors in user agreements, as in rule 6 above, refer to information that has the potential to cause instability, which is, of course, subject to decision by respective administrative authorities, and information that has not been 
confirmed by official sources (DiFonzo and Bordia, 2007; Wu, 2018; Zeng et al., 2017) [13]. For example, in 2017 the Cyberspace Administration of China issued a provision stating that netizens are allowed to repost information published by government organizations without altering the content (Cyber Space Administration of China (国家互联网信息办公室), 2017). In other words, information that has been cleared by government organizations clearly do not fall into the category of false information or rumors.

A core difference between WeChat and Weibo lies in how specific rules for deletion and blocking of content are spelled out to the user. WeChat explicitly mentions that demonstrations, illegal assembly etc. are prohibited, while Weibo uses broader terms, appealing to users to contribute to a "harmonious social network environment" or to avoid damaging "the image of the government or state organs". In other words, WeChat is more precise on prohibited content compared to Weibo.

Surprisingly for an autocratic state, Chinese companies are remarkably transparent about content management in their Chinese user agreements. While US-based companies focus on prohibited information mentioned in rules 7-11 above, Chinese companies delete or block more information and regulate content that might have negative political ramifications. With regard to false information, although both Chinese and US-based companies do not provide clear definitions of what constitutes false information in user agreements, they adopt different 
strategies towards inhibiting the spread of false information. National governments in the United States and Europe outsource the responsibility of managing false information to social media companies and place pressure on social media companies to delete posts or punish users in the event of spreading false information (Goldzweig et al., 2018) [14]. While China has followed a similar approach under Hu Jintao, under Xi Jinping the Chinese government has passed a series of legal regulations that hold individuals accountable. In practice, Chinese users are less concerned about political censorship and reactions by the regime compared to reactions by acquaintances, friends, and family. What kind of political talk is perceived to be socially desirable is more important in explaining whether people post or comment on political content online compared to fear of political repercussion or censorship (Stockmann and Luo, 2019). Legal regulations operate at this intersection between political and social norms; they provide guidelines for how to differentiate false from accurate information, thus supporting selfcensorship among what is envisioned as "socially responsible" user.

\section{Personal Information and Data Processing}

In line with the above-mentioned Chinese regulations, both Chinese companies ask users to register with real personal information. If users do not register with their real identity both services have the right to block or, in the case of Weibo, to even delete the account. Similarly, WhatsApp asks users to register with their real identity and update their information frequently. 
Only Twitter does not require the user to register with a real name [15]. Hence, WhatsApp, WeChat (PRC version) and Weibo (PRC version) require more personal information on registration compared to Twitter.

Processing data and sharing data with third parties are common practices among both Chinese and US-based social media. Weibo states in its 2019 version, that it has the right to review data and analyze user behavior or even pass it on to third parties. WeChat even states in its Privacy Policy of 2019 that Tencent will access and analyze user data without users' consent under certain conditions, such as national interests, major public interests, or criminal investigations [16]. WhatsApp and Twitter reserve the right to investigate suspicious "activity" of users in order to secure the services provided. Therefore, US-based and Chinese social media companies are similar in that they leave room for surveillance and sharing of data with third parties, including commercial and government actors. Obviously, these companies operate within different legal environments, which provide users of US-based social media with greater legal protection compared to users of Chinese social media.

\section{Trend over Time}

As explained earlier, we detected more references to relevant laws and regulations that have been passed under Xi Jinping. Changes in PRC user agreements over time reflect greater 
tightening of content management during the first five years of Xi Jinping's rule. At the same time, however, greater embeddedness of user agreements into legal rules and regulations was also associated with greater transparency, thus increasing predictability of content management among users. Yet greater transparency is not only restricted to spelling out the rules of the game for users. For example, Weibo's user agreement specifies how accounts of media and government are managed and regulated by the Cyberspace Administration Authority (网信部门) as well as the News and Information Authority (新闻主管部门) [17]. Sina also describes ties to China's political structure.

Regarding data privacy and processing data, we also detect more transparency over time. In 2014 Weibo claimed copyright over all content being published; in 2019 Weibo stated that Sina monitors and analyzes content and user behavior; Sina also specifies conditions under which users will be asked to report content or other users to the company or to government authorities. While WeChat did not provide any privacy policy in 2014, the privacy policy of 2019 requests real name and phone number as part of real identity registration. Furthermore, Tencent explicitly states to monitor or process user data if related to national interests, security, defense etc. Such references are missing in WeChat's 2014 terms of service.

A final change over time in user agreements refers to availability in English. Weibo does not provide an English version of terms of use anymore in 2019. However, WeChat provides the PRC 
User version not only in Chinese but also in English [18]. This could be related to differences in the user base of the two companies, whereby Weibo's user base has declined over time and is mainly based inside the Chinese Firewall (Benney and $\mathrm{Xu}$, 2018), while WeChat has a significant presence in Australia (Walsh and Xiao, 2019). Another possible explanation for WeChat's availability of its PRC user agreement in English is related to global operation of Chinese companies abroad since PRC Users also include employees of Chinese-incorporated firms outside of China. WeChat's user agreement does not specify the criteria of being a Chinese incorporated company as part of its definition of PRC Users. The Chinese version remains vague about its definition of “Chinese-incorporated," referring to “Chinese companies" (中国公司) operating outside of China, which could apply to companies registered in China or to companies receiving investment from Chinese companies or government regardless of their place of registration. As such, this definition could potentially have implications for employees of Chinese companies, for example, under the Belt and Road Initiative.

\section{Conclusion and Implications of Findings}

All our findings originate from two Chinese and two US-based companies at two points in time. Obviously, we cannot draw conclusions about trends in content management of Chinese and US companies more broadly. With that caveat in mind our findings suggest the following: 
First, Chinese user agreements reveal a territorial-based approach towards content management. Weibo and WeChat differentiate between PRC and Non-PRC Users. Surprisingly, the boundaries of the nation state are not the only determining factor for being considered a PRC User - Chinese citizenship alone or working for a Chinese-incorporated company are sufficient indicators to qualify as PRC User on WeChat. Similarly, traveling to China is also sufficient to be qualified as a PRC User.

Second, Chinese social media companies have become more transparent in terms of deleted content, use of personal information and data processing. Greater openness and transparency are in line with broader trends in the Chinese political system and support attempts to educate citizens to become more socially responsible (Stromseth et al., 2017; Yang, 2017). The Chinese government initiated a discourse on civil behavior to undermine criticism and its negative framing of the state (Yang, 2017). Spelling out the rules for rewarding and punishing correct behavior of users creates many 'authorities' (users) that help monitor content and behavior of other users (Stromseth et al., 2017, p. 43).

Third, references to relevant laws reflect a broader trend towards stronger content management under Xi Jinping. Since some of the laws leave room for interpretation - the definition of rumors or fake news for example - content managers are in the position to re-define them depending on directions given by relevant state authorities. New rules of prohibiting the 
spread of rumors or false information have been used to manage criticism and to silence users with large mobilization potential (Economy, 2018). In a leaked speech at the National Propaganda and Work Conference in 2013, Xi Jinping mentioned that public opinion leaders following the party line should be encouraged and those going against the official line should be restrained (Economy, 2018). As relevant laws and regulations have tightened space for public discourse under Xi Jinping, changes in PRC User agreements over time reflect greater tightening of content management during the first five years of Xi Jinping's rule.

While US-based companies tend to raise less restrictions for users, especially in the political realm compared to Chinese companies, at least WhatsApp has started to also raise false information in its user agreement. WhatsApp explicitly prohibits information that involves "publishing falsehoods, misrepresentations, or misleading statements" (WhatsApp Privacy Policy, 2018). This likely reflects greater sensitivity towards false information in the United States after the 2016 Presidential elections. In light of an emerging discourse on harmful content on social media, many national governments are taking initiative to draft, pass, and implement laws that provide the legal basis for social media companies to delete and block content deemed to destabilize societies in the eyes of policy makers. Germany's network enforcement act, implemented in 2018, is at the forefront of these developments (Goldzweig et al., 2018). National governments increasingly turn to more national-level laws and policies regarding content moderation, moving from self-regulation towards co-regulation of social media companies 
(Goldzweig et al., 2018). While Twitter and WhatsApp only referred to US law in 2014, in 2019 they also state Canadian (WhatsApp) and EU law. As user agreements of US-based companies state more national-level regulations for content management, they become more similar to Chinese user-agreements, which reflect a territorial-based vision of Internet Governance. Despite the differences in legal and government systems between both countries, future research may investigate whether US-based and Chinese user agreements will become even more similar in the future. 


\section{About the Authors}

Daniela Stockmann, PhD is Professor of Digital Governance at the Hertie School.

Email: stockmann@hertie-school.org

Felix Garten is Research Associate at the Hertie School.

Email: garten@hertie-school.org

Ting Luo, PhD, is Lecturer of Political Communication at Manchester Metropolitan University. Email: tingltlse@gmail.com

\section{Notes}

1. Authority between the Cyberspace Administration of China and the implementing ministries under the State Council remains unclear and tensions exist (Creemers, 2017).

2. Both of these means are not easily detected by netizens - Internet commentators do not uncover that they are employed by the state and error messages when searching for sensitive keywords often indicate technical difficulties rather than detecting censorship as the cause. On trends towards more subtle means of censorship see, for example: Bandurski, 2008; Boas, 2006; Brady, 2008; Chase et al., 2002; MacKinnon, 2009; Qiu, 2000.

3. During the $15^{\text {Th }}$ China Internet Conference the "China Internet Industry Self-discipline Award" was granted to about 30 enterprises (The 15th CIC successfully closed in Beijing, 2016).

4. China's Supreme People's Court and Supreme People's Procuratorate issued a new judicial interpretation in 2013 on fines or prison time for those profiting from spreading 
rumors (Chinese Defamation Law (两高发布关于办理网络诽谤等刑事案件适用法律若 干问题的解释), 2013).

5. The regulation was implemented by the Cyberspace Administration of China on 1 March 2015. It follows the decision of the Standing Committee on December 2012 to improve the network security (National People's Congress Standing Committee Decision concerning Strengthening Network Information Protection, 2012).

6. Facebook's terms of service and privacy policy is available in various languages including Chinese, but not with any specific policies towards PRC Users.

7. WhatsApp's terms of service and privacy policy is available in Chinese and other languages, and the content of the Chinese version is the same as the English one. It does not contain any rules regarding deletion or blocking of political content as in WeChat's and Weibo's user agreements.

8. Rules 1-8 are translated from the Chinese version of WeChat terms of service. The content is the same for Weibo.

9. See also (Zhao, 1998).

10. These changes include the infinite president term for $X i$ and his ideology, namely " $X i$ Jinping Thought" or "Socialism with Chinese Characteristics" in the preamble of the constitution (Dorn, 2018).

11. Tibet has been part of the PRC since 1950. Tibet's former religious leader, the Dalai Lama, lives in exile. In 2011 he officially declared the elected government of Tibet as legitimate 
(Batke, 2019). However, Tibetans still see him as a spiritual leader, which has led to much resistance against Chinese authority, both inside and outside of China.

Xinjiang has been part of the PRC since 1949 (Davis, 2008). Tensions and acts of resistance have been increasing over time, especially since the late 1990s (Rudolf et al., 2016). Most Uyghurs in China want to be able to openly live their shared Islamic culture and traditions, while a minority participates in separatist movements. The Uyghur diaspora strives to create awareness among Western publics to increase pressure on the Chinese government (Mukherjee, 2010).

Falun Gong was a self-organized movement in China with an administrative body and mobilization potential (Tong, 2002). It was officially banned in 1999.

12. In 2013 China's Supreme People's Court and Supreme People's Procuratorate issued a new judicial interpretation on fines or prison time for those profiting from spreading rumors (Chinese Defamation Law (两高发布关于办理网络诽谤等刑事案件适用法律若 干问题的解释), 2013). In 2016 a new Cyber Security Law prohibited rumors that undermine economic and social order (Cyber Security Law of the People's Republic of China (中华人民共和国网络安全法), 2016).

13. In China, any information that does not align with the official party line can potentially be considered as rumor (Repnikova, 2018).

14. WhatsApp explicitly prohibits information that involves "publishing falsehoods, misrepresentations, or misleading statements" (WhatsApp Privacy Policy, 2018).

15. Facebook requires its users to register with their real name. 
16. As of November 1, 2019, a "sovereign Russian internet" law came into effect with similar regulations, but the extent to which it has been implemented remains unclear. For example, Telegram has refused to provide the Russian government with data from its users. Russia follows China's territorial-based approach towards internet governance and is in the process of building a firewall (Polyakova and Meserole, 2019).

17. In addition to private accounts, WeChat may not refer to its relationship with the government, because the platform distinguishes between personal (private users) and public accounts (media, government, and other organizations). The use of WeChat's official account is specified by a separate user agreement (WeChat Official Account Admin Platform User Agreement), which is beyond the scope of this study.

18. Facebook, WhatsApp and Twitter provide their user agreements in many different languages. However, Twitter does not provide a Chinese version.

\section{References}

Agreement on Software License and Service of Tencent Weixin, 2019. WeChat (微信), at https://weixin.qq.com/cgibin/readtemplate?lang $=$ en $\& \mathrm{t}=$ weixin_agreement\&s $=$ default\&cc $=\mathrm{CN}$, accessed 8 July 2019.

Agreement on Software License and Service of Tencent Weixin PRC User (腾讯微信软件许可 及服务协议), 2019. WeChat (微信), at https://weixin.qq.com/cgibin/readtemplate?lang=zh_CN\&t=weixin_agreement\&s=default, accessed 8 July 2019.

D. Bandurski, 2008. "China's Guerrilla War for the Web," Far Eastern Economic Review, at http://chinamediaproject.org/2008/07/07/feer-chinas-guerrilla-war-for-the-web/, accessed 9 September 2019. 
Jessica Batke, 2019. "Is This the Last Dalai Lama?," China File, at http://www.chinafile.com/reporting-opinion/viewpoint/last-dalai-lama, accessed 20 August 2019.

Jonathan Benney and Jian Xu, 2018. "The Decline of Sina Weibo: A Technological, Political and Market Analysis," In: M. Kent, K. Ellis and J. Xu (editors). Chinese Social Media: Social, Cultural, and Political Implications, New York: Routledge, pp. 221-235, and at https://doi.org/10.4324/9781315160214.

Taylor C. Boas, 2006. "Weaving the Authoritarian Web: The Control of Internet Use in Nondemocratic Regimes," In: J. Zysman and A. Newman (editors). How Revolutionary Was the Digital Revolution? National Responses, Market Transitions, and Global Technology., Stanford CA: Standford Business Books.

A.-M. Brady, 2008. Marketing Dictatorship: Propaganda and Thought Work in Contemporary China., Lanham: Rowman \& Littlefield.

Christopher Cairns, 2016. "Fragmented Authoritarianism? Reforms to China's Internet censorship system under Xi Jinping," draft presented at the American Political Science Association Annual Meeting, p. 36.

Edoardo Celeste, 2019. "Terms of service and bills of rights: new mechanisms of constitutionalisation in the social media environment?," International Review of Law, Computers \& Technology, volume 33, number 2, pp. 122-138.

Micheal Chase, James C. Mulvenon and Rand Corporation, 2002. You've Got Dissent! Chinese Dissident Use of the Internet and Beijing's Counter-strategies, Santa Monica CA: RAND Corporation.

Nick Cheesman, 2014. "Law and Order as Asymmetrical Opposite to the Rule of Law," Hague Journal on the Rule of Law, volume 6, number 01, pp. 96-114.

Chinese Defamation Law (两高发布关于办理网络诽谤等刑事案件适用法律若干问题的解释

), 2013. The Surpreme People's Procuratorate of the People's Republic of China (中华人 民共和国最高人民法院)，at

http://www.spp.gov.cn/zdgz/201309/t20130910_62417.shtml, accessed 9 September 2019.

Rogier Creemers, 2017. “Cyber China: Upgrading Propaganda, Public Opinion Work and Social Management for the Twenty-First Century," Journal of Contemporary China, volume 26, number 103, pp. 85-100.

Rogier Creemers, 2013. "Xi Jinping's 19 August speech revealed? (Translation)," China Copyright and Media, at https://chinacopyrightandmedia.wordpress.com/2013/11/12/xijinpings-19-august-speech-revealed-translation/. 
Cyber Security Law of the People's Republic of China (中华人民共和国网络安全法), 2016.

Peking University Law (北大法律), at

http://www.pkulaw.cn/fulltext_form.aspx?Db=chl\&Gid=283838, accessed 18 July 2019.

Cyber Space Administration of China (国家互联网信息办公室), 2017. “Internet News

Information Service Regulations (互联网新闻信息服务管理规定),”Peking University

Law (北大法律), at

http://en.pkulaw.cn/display.aspx?cgid=8d18a3f4334a2686bdfb\&lib=law, accessed 18 July 2019.

Elizabeth Van Wie Davis, 2008. "Uyghur Muslim Ethnic Separatism in Xinjiang, China," Asian Affairs: An American Review, volume 35, number 1, pp. 15-30.

N. DiFonzo and P. Bordia, 2007. Rumor psychology: Social and organizational approaches, Washington D.C.: American Psychological Association.

Laura Dombernowsky, 2016. "Training Responsible Journalists in China: Guiding Domestic Opinion, Gaining Foreign Audiences," Journal of Current Chinese Affairs, volume 45, number 3, pp. 175-200.

James A. Dorn, 2018. "Why Xi Jinping Thought Is a Threat to China's Future," The Diplomat, at https://thediplomat.com/2018/08/why-xi-jinping-thought-is-a-threat-to-chinas-future/, accessed 17 July 2019.

Elizabeth C. Economy, 2018. The Third Revolution: Xi Jinping and the New Chinese State, New York: Oxford University Press.

Rafael Goldzweig, Marie Wachinger, Daniela Stockmann and Andrea Römmele, 2018. "Beyond Regulation: Approaching the challenges of the new media environment," Dahren Dorf Forum IV, volume 6, p. 25.

Sebastian Heilmann edAA, 2016. Das politische System der Volksrepublik China, Wiesbaden: Springer Fachmedien Wiesbaden, at http://link.springer.com/10.1007/978-3-658-072285, accessed 28 November 2019.

Arne Hintz, 2016. "Restricting digital sites of dissent: commercial social media and free expression," Critical Discourse Studies, volume 13, number 3, pp. 325-340.

Arne Hintz and S. Milan, 2011. "User Rights for the Internet Age: Communications Policy According to Netizens," In: R. Mansell and M. Raboy (editors). The Handbook of Global Media and Communication Policy, Oxford: Wiley-Blackwell, pp. 230-241.

Harrison Jacobs, 2019. "Mark Zuckerberg's vision for Facebook sounds a lot like China, where I couldn't buy a cup of coffee without the app that dominates people's lives there," 
Business Insider, at https://www.businessinsider.de/future-of-facebook-looks-like-chinawechat-2019-3? r=US\&IR=T, accessed 8 August 2019.

O. Leistert, 2015. "The Revolution Will Not Be Liked: On the Systematic Constraints of Corporate Social Media Platforms for Protest," In: L. Dencik and O. Leistert (editors). Critical Perspectives on Social Media and Protest: Between Control and Emancipation, Lanham: Rowman and Littlefield, pp. 35-52.

Barbara Li, 2015. "China requires providers to enforce real-name registration and ban on 'harmful' usernames," Data Protection Report, at https://www.dataprotectionreport.com/2015/02/china-requires-real-name-registration-andbans-harmful-usernames/, accessed 5 July 2019.

Kenneth Lieberthal and David M. Lampton edsAA, 1992. Bureaucracy, Politics, and Decision Making in Post-Mao China, Studies on China, Berkeley: University of California Press.

Benjamin L. Liebman, 2017. “Authoritarian Justice in China: Is There a 'Chinese Model'?,” In: W. Chen (editor). The Beijing Consensus?, Cambridge: Cambridge University Press, pp. 225-248, and at https://www.cambridge.org/core/product/identifier/CBO9781316481370A020/type/book_ part, accessed 4 June 2019.

Benjamin L. Liebman, 2011. "The Media and the Courts: Towards Competitive Supervision?," The China Quarterly, volume 208, pp. 833-850.

Geert Lovink edAA, 2013. Unlike us Reader: social media monopolies and their alternative, Amsterdam: Inst. of Network Cultures.

R. MacKinnon, 2009. "China's censorship 2.0: How companies censor bloggers," First Monday, volume 14, number 2, at https://firstmonday.org/article/view/2378/2089, accessed 9 September 2019.

Edmund J. Malesky, Jonathan R. Stromseth, Dimitar D. Gueorguiev, Lai Hairong, Wang Xixin and Carl Brinton, 2017. China's Governance Puzzle: Enabling Transparency and Participation in a Single-Party State, Cambridge: Cambridge University Press, at http://ebooks.cambridge.org/ref/id/CBO9781316388501, accessed 6 December 2019.

Kunal Mukherjee, 2010. "The Uyghur Question in Contemporary China," Strategic Analysis, volume 34, number 3, pp. 420-435.

National People's Congress Standing Committee Decision concerning Strengthening Network Information Protection, 2012. China Copyright and Media, at https://chinacopyrightandmedia.wordpress.com/2012/12/28/national-peoples-congressstanding-committee-decision-concerning-strengthening-network-information-protection/, accessed 5 July 2019.

Alina Polyakova and Chris Meserole, 2019. Exporting digital authoritarianism: The Russian and Chinese models, Brookings, at https://www.brookings.edu/wp- 
content/uploads/2019/08/FP_20190827_digital_authoritarianism_polyakova_meserole.pd $\mathrm{f}$, accessed 6 December 2019.

J.L. Qiu, 2000. "Virtual Censorship in China: Keeping the Gate Between the Cyberspaces." International Journal of Communications Laws and Policy," International Journal of Communications Laws and Policy, volume 4, pp. 1-25.

Maria Repnikova, 2018. "China's Lessons for Fighting Fake News," Foreign Policy, at https://foreignpolicy.com/2018/09/06/chinas-lessons-for-fighting-fake-news/, accessed 3 July 2019.

Moritz Rudolf, Johannes Buckow and Marc Julienne, 2016. "Neue Gefahren, Neue Antworten: Wie China den Terrorismus bekämpft," Mercator Institute for China Studies, at http://www.merics.org/de/merics-analysen/dossierweb-spezial/wie- china-denterrorismus-bekaempft.html., accessed 23 January 2016.

Jacob Silverman, 2015. Terms of Service: Social Media and the Price of Constant Connection, 1st ed., Harper Collins.

Sina Weibo: Personal Information Protection Policy, 2019. Sina Weibo, at https://m.weibo.cn/page/647?entry=client, accessed 9 September 2019.

Sina Weibo Terms of Service, 2013. Sina Weibo, at http:/www.weibo.com/signup/v5/protocol, accessed 31 July 2014.

Statistical Report on Internet Development in China, 2018., China Internet Network Information Center (CNNIC).

Daniela Stockmann, 2013. Media commercialization and authoritarian rule in China MLA (Modern Language Assoc.) Stockmann, Daniela. Media Commercialization and Authoritarian Rule in China. Cambridge University Press, 2013. APA (American Psychological Assoc.) Stockmann, D. (2013). Media Commercialization and Authoritarian Rule in China. Cambridge: Cambridge University Press., New York: Cambridge University Press.

Daniela Stockmann and Ting Luo, 2019. "Authoritarian Deliberation 2.0: Lurking and Discussing Politics in Chinese Social Media," In: M.X. Delli Carpini (editor). Digital media and democratic futures, Democracy, Citizenship, and Constitutionalism, Philadelphia: University of Pennsylvania Press, pp. 169-96.

Jonathan Stromseth, Malesky Edmund and Gueorguiev Dimitar, 2017. "Concept, Chronology, and Drivers of Transparency Reform," In: China's Governance Puzzle: Enabling Transparency and Participation in a Single-Party State, New York: Cambridge University Press, pp. 26-59.

The 15th CIC successfully closed in Beijing, 2016. Internet Society of China, at http://www.isc.org.cn/english/Focus/listinfo-33774.html, accessed 9 September 2019. 
James Tong, 2002. "An Organizational Analysis of the Falun Gong : Structure, Communications, Financing," The China Quarterly, volume 171, pp. 636-660.

Jingrong Tong, 2019. "The Taming of Critical Journalism in China: A combination of political, economic and technological forces," Journalism Studies, volume 20, number 1, pp. 7996.

Twitter Privacy Policy, 2013. Wayback Machine, at http://web.archive.org/web/20131231222021/https://twitter.com/privacy, accessed 22 July 2019.

Twitter Privacy Policy, 2018. Twitter, Inc., at https://twitter.com/en/privacy, accessed 9 September 2019.

Twitter Terms of Service, 2014. Wayback Machine, at http://web.archive.org/web/20131231173610/https://twitter.com/tos, accessed 22 July 2019.

Twitter Terms of Service, 2018. Twitter, Inc., at https://twitter.com/en/tos, accessed 9 September 2019.

Visualizing China's Anti-Corruption Campaign, 2018. China File, at http://www.chinafile.com/infographics/visualizing-chinas-anti-corruption-campaign, accessed 28 November 2019.

Micheal Walsh and Bang Xiao, 2019. “'Uncharted territory': WeChat's new role in Australian public life raises difficult questions," $A B C N e w s$, at https://www.abc.net.au/news/201904-19/wechats-new-role-in-australian-politics-raises-questions/11031878, accessed 14 August 2019.

Juan Wang and Wenting Liang, 2019. "Political Resources and Divergent Court Empowerment in China: A Subnational Comparison,” Modern China, volume 45, number 6, pp. 629 665.

Juan Wang and Sida Liu, 2019. "Ordering Power under the Party: A Relational Approach to Law and Politics in China," Asian Journal of Law and Society, volume 6, number 01, pp. 1-18.

WeChat - Terms of Service, 2018. WeChat, at https://www.wechat.com/en/service_terms.html, accessed 8 July 2019.

WeChat 一 服務條款 (WeChat Terms of Service Non-PRC User), 2014. Wayback Machine, at https://web.archive.org/web/20140920215115/http://www.wechat.com/zh_TW/service_te rms.html, accessed 9 September 2019.

WeChat Privacy Policy, 2014. Wayback Machine, at https://web.archive.org/web/20140920233455/http://www.wechat.com/en/privacy_policy. html, accessed 9 September 2019. 
WeChat Privacy Policy (微信隐私保护指引), 2018. WeChat (微信), at https://weixin.qq.com/cgi-

bin/readtemplate?lang=zh_CN\&t=weixin_agreement\&s=privacy, accessed 8 July 2019.

WeChat Privacy Policy (私隱政策), 2014. WeChat, at http://www.wechat.com/zh_TW/privacy_policy.html, accessed 21 November 2014.

WeChat Terms of Service, 2014. Wayback Machine, at https://web.archive.org/web/20140920233458/http://www.wechat.com/en/service_terms.h tml, accessed 9 September 2019.

WeChat Terms of Service (服務條款), 2018. WeChat, at https://www.wechat.com/zh_TW/service_terms.html, accessed 8 July 2019.

WeChat Terms of Service (腾讯微信使用条款和隐私政策(腾讯微信), 2014. Wayback Machine, at http://weixin.qq.com/cgibin $/$ readtemplate? uin $=\&$ stype $=\&$ promote $=\& \mathrm{fr}=\&$ lang $=$ zh $\_$CN\&ADTAG $=\&$ check $=$ false $\& n a v=$ faq $\&$ t=weixin_agreement\&s=default, accessed 9 September 2019.

Weibo Online Service Agreement, 2019. Sina Weibo, at https://m.weibo.cn/c/regagreement?from=h5\&lang=en_US, accessed 9 September 2019.

Weibo Privacy Policy (微博个人信息保护政策), 2019. Sina Weibo, at https://www.weibo.com/signup/v5/privacy, accessed 9 September 2019.

Weibo Privacy Policy (新浪微博个人信息保护政策), 2014. Wayback Machine, at https://web.archive.org/web/20140209115541/http://www.weibo.com/signup/v5/privacy, accessed 9 September 2019.

Weibo Terms of Service (微博服务使用协议), 2019. Sina Weibo, at https://www.weibo.com/signup/v5/protocol, accessed 7 August 2019.

Weibo Terms of Services (新浪微博服务使用协议), 2014. Wayback Machine, at https://web.archive.org/web/20140209105045/http:/www.weibo.com/signup/v5/protocol, accessed 9 September 2019.

Weixin Privacy Protection Guidelines, 2018. WeChat (微信), at https://weixin.qq.com/cgi$\mathrm{bin} /$ readtemplate$?$ lang $=$ en $\& \mathrm{t}=$ weixin_agreement $\& \mathrm{~s}=$ privacy $\& \mathrm{cc}=\mathrm{CN}$, accessed 8 July 2019.

WhatsApp Privacy Notice, 2014. Wayback Machine, at http://web.archive.org/web/20140122055233/http://www.whatsapp.com/legal/\#Privacy, accessed 22 July 2019. 
WhatsApp Privacy Policy, 2018. WhatsApp, at https://www.whatsapp.com/legal/?eea=1\&lang=en\#privacy-policy, accessed 22 July 2019.

WhatsApp Terms of Service, 2014. Wayback Machine, at http://web.archive.org/web/20140122055233/http://www.whatsapp.com/legal/, accessed 22 July 2019.

WhatsApp Terms of Service, 2018. WhatsApp, at https://www.whatsapp.com/legal/?eea=1\&lang=en\#terms-of-service, accessed 22 July 2019.

Xiaoping Wu, 2018. "Discursive strategies of resistance on Weibo: A case study of the 2015 Tianjin explosions in China," Discourse, Context \& Media, volume 26, pp. 64-73.

Guobin Yang, 2017. "Demobilizing the Emotions of Online Activism in China: A Civilizing Process," International Journal of Communication, pp. 1945-1965.

William Lafi Youmans and Jillian C. York, 2012. "Social Media and the Activist Toolkit: User Agreements, Corporate Interests, and the Information Infrastructure of Modern Social Movements," Journal of Communication, volume 62, number 2, pp. 315-329.

J. Zeng, C. Chan and K. Fu, 2017. "How Social Media Construct “Truth" Around Crisis Events: Weibo's Rumor Management Strategies After the 2015 Tianjin Blasts," Policy \& Internet, volume 9, pp. 297-320.

Yuezhi Zhao, 1998. Media, Market, and Democracy in China: Between the Party Line and the Bottom Line, Urbana: University of Illinois Press.

(C) 2019 Daniela Stockmann, Felix Garten and Ting Luo All Rights Reserved.

Table 1: China and US-based Social Media Terms of Service [7].

\begin{tabular}{|l|l|l|l|l|l|}
\hline Social & & Terms of & Privacy Policy & Terms of & Privacy Policy \\
Media & Version & Service (PRC & Service (Non- & (Non-PRC \\
& & Users) & (PRC Users) & PRC Users) & Users) \\
\hline
\end{tabular}




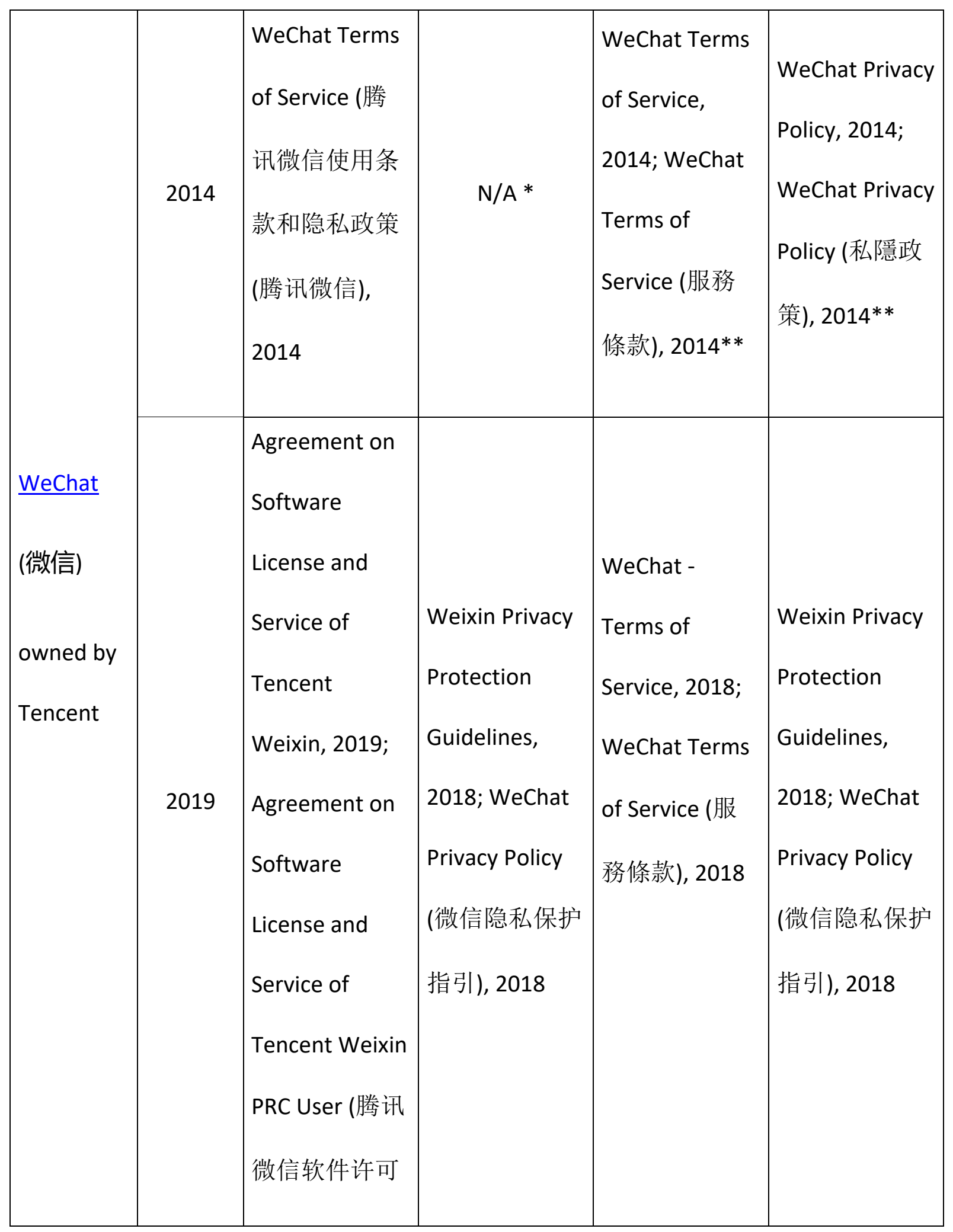




\begin{tabular}{|c|c|c|c|c|c|}
\hline & & $\begin{array}{l}\text { 及服务协议), } \\
2019\end{array}$ & & & \\
\hline Whatsapp & 2014 & $\mathrm{~N} / \mathrm{A}$ & $\mathrm{N} / \mathrm{A}$ & $\begin{array}{l}\text { WhatsApp } \\
\text { Terms of } \\
\text { Service, } 2014\end{array}$ & $\begin{array}{l}\text { WhatsApp } \\
\text { Privacy Notice, } \\
2014\end{array}$ \\
\hline Facebook & 2019 & $\mathrm{~N} / \mathrm{A}$ & $\mathrm{N} / \mathrm{A}$ & $\begin{array}{l}\text { WhatsApp } \\
\text { Terms of } \\
\text { Service, } 2018\end{array}$ & $\begin{array}{l}\text { WhatsApp } \\
\text { Privacy Policy, } \\
2018\end{array}$ \\
\hline Weibo (新 & 2014 & $\begin{array}{l}\text { Weibo Terms } \\
\text { of Services (新 } \\
\text { 浪微博服务使 } \\
\text { 用协议), } 2014\end{array}$ & $\begin{array}{l}\text { Weibo Privacy } \\
\text { Policy (新浪微 } \\
\text { 博个人信息保 } \\
\text { 护政策), } 2014\end{array}$ & $\begin{array}{l}\text { Sina Weibo } \\
\text { Terms of } \\
\text { Service, } 2013\end{array}$ & N/A* \\
\hline $\begin{array}{l}\text { owned by } \\
\text { Sina }\end{array}$ & 2019 & $\begin{array}{l}\text { Weibo Terms } \\
\text { of Service (微 } \\
\text { 博服务使用协 } \\
\text { 议), } 2019\end{array}$ & $\begin{array}{l}\text { Weibo Privacy } \\
\text { Policy (微博个 } \\
\text { 人信息保护政 } \\
\text { 策), } 2019\end{array}$ & $\begin{array}{l}\text { Weibo Online } \\
\text { Service } \\
\text { Agreement, } \\
\text { 2019*** }\end{array}$ & $\begin{array}{l}\text { Sina Weibo: } \\
\text { Personal } \\
\text { Information } \\
\text { Protection } \\
\text { Policy, } 2019\end{array}$ \\
\hline
\end{tabular}




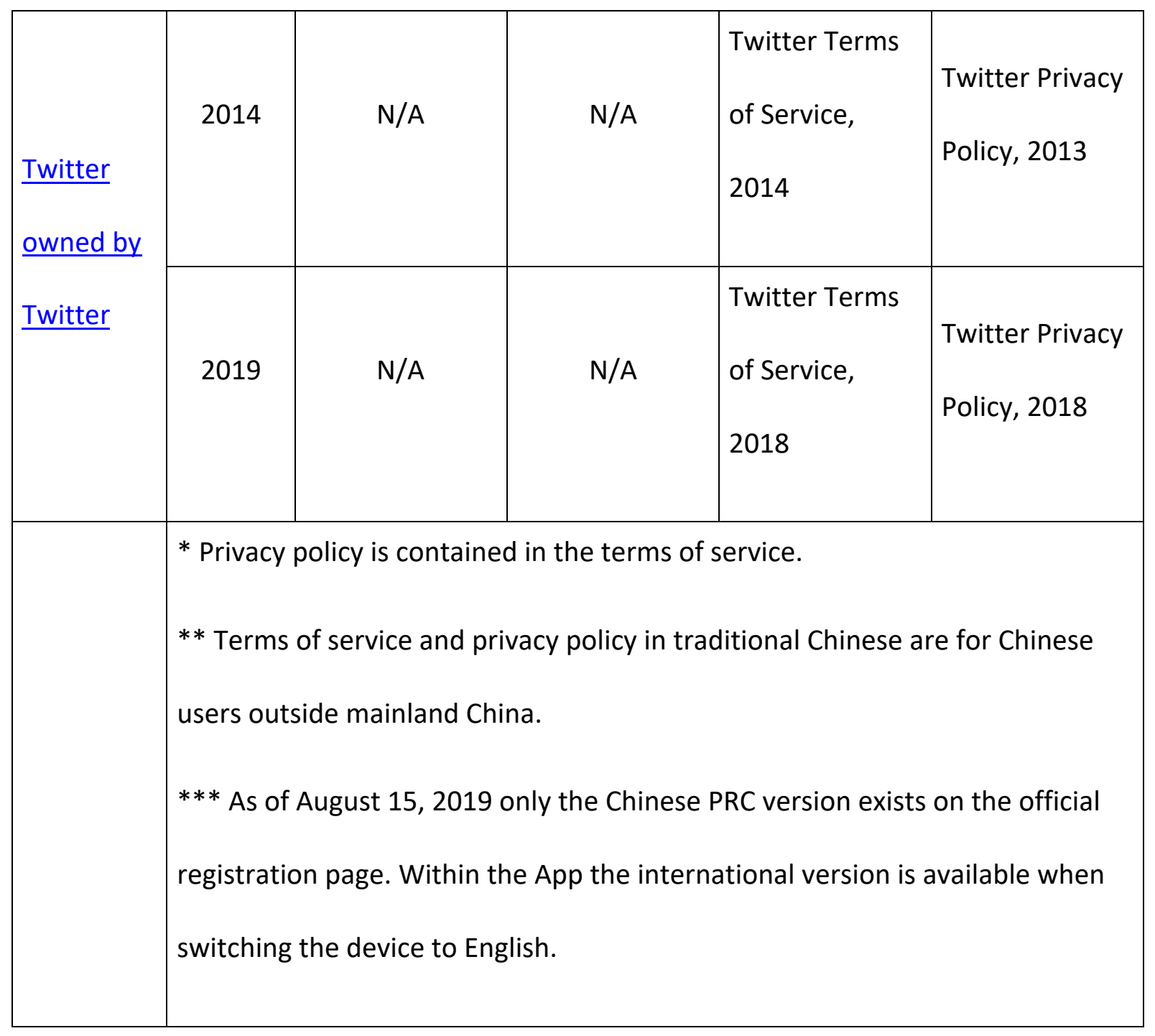

